\title{
Intervention "Premenopause Empowerment Model (PEM)" to Change Health Belief in the Control of Perimenopause Complaints in Pematangsiantar City, Indonesia
}

\author{
Dame Evalina Simangunsong ${ }^{1}$, Rosa Delima Ekwantini ${ }^{1} \&$ Marlisa $^{2}$ \\ ${ }^{1}$ Department of Nursing, Poltekkes Kemenkes Medan, Indonesia \\ ${ }^{2}$ Department of Nursing, Poltekkes Kemenkes DI Yogyakarta, Indonesia \\ Correspondence: Dame Evalina Simangunsong, Department of Nursing, Poltekkes Kemenkes Medan, Indonesia. \\ Tel: 62-853-6252-8615.
}

Received: May 2, 2021 Accepted: June 23, 2021 Online Published: July 6, 2021

doi:10.5539/gjhs.v13n8p56 URL: https://doi.org/10.5539/gjhs.v13n8p56

\begin{abstract}
Prevention efforts against the effects of decreased estrogen hormones are very noteworthy, these conditions can lead to a variety of health problems and are very much complained of in the perimenopause period. This research is to achive the improvement of premenopausal women's Health Belief by using PEM for the perimenopause period. The research will involve two Group Design pretest-Posttest with control group that took the location in two sub districts involving women aged $40 \mathrm{yr}$ to $45 \mathrm{yr}$, as many as 70 people The quasi-experimental designed study employed two groups: the pretest-posttest and control group and was conducted at two sbdistricts: Kahean, for the control group, and Tomuan, for the intervention group. Data processed with univariate and bivariate analysis, sufficient with $\mathrm{t}$ test. The results showed that there was an increase in the health belief score before the intervention (59.74 \pm 7.01$)$, after the intervention (76.89 \pm 9.70$)$ with $\mathrm{P}=<0.001$. The provision of information based on Health Belief Model in the study able to change the perception of premenopause community in the village Tomuan, shown by increasing the value of the perception of seriousness and vulnerability to the interference that will be experienced and can considering the gains to be gained so decided to behave as expected. It is recommended that women empowerment premenopause with sustainable PEM and the development of health service efforts in the community through Peer Education.
\end{abstract}

Keywords: belief, climacterium, estrogen perception

\section{Introduction}

The transitional period between the reproductive period and the senium period will be experienced by a woman, lasting from $35 \mathrm{yr}$ to $65 \mathrm{yr}$ of age, the journey of life in the age of $40 \mathrm{yr}$ to $50 \mathrm{yr}$ is a crisis experience in her, which will be old and menopause. This period is very complex for women because it relates to its physical and psychological circumstances (Baziad, 2003; Rachman et al., 2004). Psychological changes also greatly affect the quality of life of a woman in the period of menopause (Sriwaty \& Nuryoto, 2015). Many perimenopause women in Kenya, (aged $40 \mathrm{yr}$ to $45 \mathrm{yr}$ ) have low knowledge of perimenopause, including symptoms experienced, health care facilities and health resources do not provide clear information about the circumstances their face (Achar \& Odero, 2014). Found in Lyari General Hospital, Karachi of 170 women aged 45 yr to 60 yr, as many as $46 \%$ are aware of complaints experienced with health effects, most of them are disturbed by menopausal symptoms, but very few go to the doctor consult (Rostiana \& Kurniati, 2009). The results of the observation and in-depth interviews with women aged $45 \mathrm{yr}$ to $50 \mathrm{yr}$ showed that women are difficult to accept menopause because they are not ready to confront them and lack of information (Khokhar, 2013). The long-term impact of the loss of estrogen raises a variety of health problems especially degenerative diseases (Harpaz \& Wolff, 2012). Women whose weight rises are more likely to experience a decline in quality of life. Higher Body Mass Index (BMI) is correlated with higher scores of menopausal symptoms, resulting in an increase in weight as age needs to be wary, due to an adequate or overweight occurrence due to impaired carbohydrate metabolism (Harpaz \& Wolff, 2012; Moilanen et al., 2012). The knowledge of the perimenopause period is very low in different regions and countries, it can result in the mother experiencing menopausal complaints can feel confused and worried about the situation. Simangunsong, found the low knowledge of perimenopause woman about the period complaint of the Climacteric (77.1\%) and low utilization of healthcare services in relation to complaints that have been $44.3 \%$ in perimenopause women in 
Pematangsiantar in 2009 (Simangunsong, 2009).Studies of various literature have shown no effort in health promotion intervention in premenopausal women. The results showed various identification of complaints that had been experienced in perimenopause and menopause periods. It's time to think of a proper preventive effort to prepare a woman in a healthy and self-reliant life in a perimenopausal period. As stated in the UU Kesehatan (Health Act) No.36/2009, that health is a health physical, mental, spiritual and social state that allows everyone to live socially and economically productive lives. Incidence Perimenopause is at middle age, hence socialization as early as possible should be done at the previous age. The efforts of the health promotion that can be interpreted, as behaviors motivated by the desire to improve welfare and actualize human potential, are effective to change to positive behavior and lower health care costs (Murdaugh et al., 2018). Most of the research on the risk factors of perimenopause complaints is related to medical clinical, but there are other factors that affect the incidence of maternal behavior. Based on the theory of Health Belief Model (HBM) The occurrence of behavior in an individual because of the perception of the susceptibility affected by a disease and the severity of the disease that will suffer. Behavior will occur when there are benefits and effectiveness of behavior, as well as the ability of individuals to overcome barriers to conduct a behavior (Innstrand, 2012). Individuals will behave in avoiding illness when individuals believe in disease, and have the feeling that the benefits of behavior are higher than the cost incurred (Champion \& Skinner, 2008). Positive perception and acceptance of menopause is influenced by value, belief and culture. It is believed to be a force in preventing various pathological problems of the menopause process (Melby et al., 2005). Culture can be categorized based on traditional way of life, modern and as a newcomer. Different perceptions and experiences of menopause symptoms as well as a variety of factors that can be modified and not, can affect the distress rate of menopausal women (Hall et al., 2007). Approach through the empowerment of premenopausal women with premenopausal Empowerment Model (PEM) which contains information about the knowledge of changes that will be experienced by women in the end of the reproductive period, threats of diseases caused by diminished and loss Estrogen, a healthy lifestyle as an alternative attempt to reduce complaints and prevention efforts against the long-term effects of loss of estrogen, diet (frequency and intake of meals) and physical activity can be administered before the perimenopause period arrives.

\section{Method}

The quasi-experimental designed study employed two groups: The pretest-posttest and control group and was conducted at two subdistricts: Kahean, for the control group, and Tomuan, for the intervention group. The study was carried out for $3 \mathrm{mo}$, with three times of intervention, from November 2016 to January 2017. The population in this study was premenopausal woman aged $40 \mathrm{yr}$ to $45 \mathrm{yr}$ living in the city of Pematangsiantar, Indonesia. Sampling was performed using technical purposive sampling based on inclusion and exclusion criteria. After calculation, a sample size of 30 women were obtained for each group, however, to avoid drops out or lost follow ups, the samples size was increased to 35 women for each group, intervention and control group. The type of research used is quasi experimentation with the design of two group design pretest-posttest with control group (Murti, 2003). The instrument used is a Health Belief questionnaire of 26 statements, a knowledge questionnaire. Ethics research: Health Research Ethics Committee of the Faculty of Nursing at the University of North Sumatera (No. 1058/X/SP/2016). Statistic analysis processed with univariate and bivariate analysis, sufficient with t test, with result in Table 1.

\section{Results}

Changes in confidence perception indicators after intervention can be seen in the table below:

Table 1. Change of health belief indicators

\begin{tabular}{|c|c|c|c|c|c|c|c|}
\hline \multirow{4}{*}{$\begin{array}{l}\text { Health Belief indicators } \\
\text { Perceived Susceptibility }\end{array}$} & \multirow{3}{*}{$\begin{array}{l}\text { Category } \\
\text { High }\end{array}$} & \multicolumn{6}{|c|}{ Intervention } \\
\hline & & \multicolumn{2}{|c|}{$I(n=35)$} & \multicolumn{2}{|c|}{ II $(n=35)$} & \multicolumn{2}{|c|}{ III $(n=35)$} \\
\hline & & 18 & 51.4 & 28 & 80 & 34 & 97.1 \\
\hline & Low & 17 & 48.6 & 7 & 20 & 1 & 2.9 \\
\hline \multirow{2}{*}{ Perceived Severity } & High & 20 & 57.1 & 28 & 80 & 32 & 91.4 \\
\hline & Low & 15 & 42.9 & 7 & 20 & 3 & 8.6 \\
\hline \multirow{2}{*}{ Perceived Benefit } & High & 24 & 68.6 & 24 & 68.6 & 27 & 77.1 \\
\hline & Low & 11 & 31.4 & 11 & 31.4 & 8 & 22.9 \\
\hline \multirow{2}{*}{ Perceived Barriers } & High & 13 & 37.1 & 21 & 60 & 28 & 80 \\
\hline & Low & 22 & 62.9 & 14 & 40 & 7 & 20 \\
\hline
\end{tabular}


The table shows the change in the perception of individual beliefs on the susceptibility and severity of health disorders that will occur before and after the onset of menopause is also the perception of benefits and barriers to be felt when decided to seek health care assistance, after being given the PEM intervention.

Table 2. Average health belief score after intervention i, ii, iii

\begin{tabular}{lll}
\hline Health Belief & Mean \pm SD & p \\
\hline Intervention I & & \\
Pretest & $59.74 \pm 7.01$ & 0.001 \\
Posttest & $64.40 \pm 8.92$ & \\
\hline Intervention 2 & & \\
Pretest & $66.71 \pm 7.45$ & 0.004 \\
Posttest & $70.57 \pm 8.52$ & \\
\hline Intervention 3 & & $<0.001$ \\
Pretest & $72.20 \pm 7.62$ & \\
Posttest & $76.89 \pm 9.70$ & \\
\hline
\end{tabular}

The table shows the occurrence of changes in the mean increase of health belief premenopausal woman significantly $(\mathrm{p}<0.005)$ on each of the PEM intervention conducted.

\section{Discussion}

\subsection{The Effect of PEM on Health Belief}

Changes in perception on health belief components after the application of PEM using a pocketbook, indicating the difference in health components belief before and after intervention in the intervention group. As presented in Table 2, there is an increase in the health belief component variable category after the moderate PEM intervention and it indicates there is a difference in the rate increase in health belief, the value $\mathrm{p}<0.001$.

HBM is a cognitive model that means individual behaviour is influenced by the cognitive processes within itself. That is influenced by demographic factors, socio psycological characteristics, and structural variables.

The results of this research are in line with research conducted by Tehrani et al. and Zohrehkhoshnood et al., who make preventive efforts by providing education based on health model belief against the case of urinary tract infections in Tehran and prevention of osteoporosis in mothers and daughters (Javaheri Tehrani et al., 2014; Zohrehkhoshnood et al., 2015).

The Health Belief Model (HBM) is often considered to be the main framework in human health-related behaviors. This makes HBM a Model that explains a person's consideration before they behave healthily. Therefore, HBM has a function as a preventative or preventive model (Williams \& Rhodes, 2016).

The Health Belief Model has four main components such as individual perception of the vulnerability affected by an illness (perceived susceptibility). This vulnerability refers to beliefs about the likelihood of a person to be exposed to disease. This Model predicts that premenopausal women are more likely to adhere to healthy lifestyle changes if they are susceptible to long-term impacts of deficiency or loss of estrogen in the body. Perceptual perception (perceived severity), this refers to the feeling of premenopausal women in assessing how serious the condition of health problems will occur and the consequences posed by these health problems when left untreated prevented or handled. Perception of perceived benefits occurs when a person senses vulnerable for a serious health condition, and that perception causes a change in behavior that will be influenced by one's beliefs regarding the perceived benefits of Various preventive measures. Perceptions of perceived obstacles refer to the negative and conflicting aspects of a preventive measure.

The results of the research on the change of the health belief indicator of premenopausal women (Table 1) showed a good change, where the perception statement of the intervention group of interventions at each stage experienced an increase. This demonstrates the cognitive processes in receiving the stimulus in the form of health information about deficiencies until the loss of estrogen in the female body turns out to be a risk factor against the various Climacteric syndrome and degenerative diseases. A total of $97.1 \%$ of premenopausal women who received training in this study have had a good perception of vulnerability, so predictable preventive efforts can be made 
before a climacteric complaint or syndrome arises.

The perception of seriousness, as much as $91.1 \%$ of the premenopausal woman intervention Group has undergone a change in the seriousness of perception towards the better. Respondents have known and understood that decreasing estrogen production although a natural process can lead to serious illnesses that can interfere with the health status of women. Short-term complaints that will be experienced and although temporary is found to interfere with the quality of life or interfere with their daily functioning in their daily activities involving the productivity of their work. Long-term complaints in the form of osteoporosis, blood circulation disorders that cause various disorders of the heart and weight gain tendency can also be a risk factor for the incidence of increased blood pressure.

The change in indicators of the perceived benefits expressed by the intervention group experienced a good change after obtaining the PEM (77.1\%). The achievement of the indicator changes is smaller than the three changes in other indicators. This can indicate that, the intervention group has not felt the vulnerability for serious health conditions because it has not felt any complaints that will occur. The stated change of indicator is still a closed stance of the intervention group against the barriers of preventive efforts that will be carried out in connection with the health problems that will be encountered.

The change in indicators of the perception of obstacles expressed by the intervention group experienced a good change in every intervention conducted $(80 \%)$. This demonstrates a negative and conflicting aspect of committing a precautionary measure. Health information provided able to increase its insight into the health condition that will be experienced and the health maintenance efforts that will be done.

Individual perception of the vulnerability and severity of an illness resulted in a perception of how much the threat of disease occurred against it. Consideration of the gains gained from expected behavior and consideration of the surrounding environment would be a consideration in approving expected behavior or not, until finally decided to behave as expected (Cues to action) due to signs or symptoms of self-existence or others; Information, both from mass media and from healthcare personnel.

Bayat et al. provides health education interventions based on Health Belief Model for 3 months and 6 months. Educational programs have a positive impact on health including vulnerability, seriousness or intensity, benefits, perceived barriers and self-efficacy in experimental groups. Education is an important factor that affects health belief individuals (Bayat et al., 2013). Relationship between the knowledge of osteoporosis, health belief and calcium intake in students. The study also examines perceived vulnerabilities, severity, benefits, barriers and selfefficacy related to the prevention of osteoporosis. The results showed that individuals would take precautions when knowing that osteoporosis was prone to occur with him (Edmonds et al., 2012).

The perception of individuals in conducting or choosing healthy behaviors, determining the attitude of yes or no health conduct can be examined in the Health Belief Model (Conner \& Norman, 2005). In this study, the influence of PEM intervention on changes in HBM components showed significant results so that health education is a factor that affects the health belief of a person. Reproductive health information in the perimenopausal period through PEM intervention is able to change the health belief premenopause women, so as to show the change of attitude to be independent in making the expected prevention efforts.

\section{Competing Interests Statement}

The authors declare that there are no competing or potential conflicts of interest.

\section{References}

Achar, D. A., \& Odero, D. (2014). Knowledge of Perimenopausal Phase and Symptoms Women Experienced in Njoro District, Kenya.

Bayat, F., Shojaeezadeh, D., s, M., Heshmat, R., Baikpour, M., \& Hosseini, M. (2013). The effects of education based on extended health belief model in type 2 diabetic patients: A randomized controlled trial. Journal of Diabetes and Metabolic Disorders. https://doi.org/10.1186/2251-6581-12-45

Baziad, A. (2003). Menopause dan andropause. Jakarta: Yayasan Bina Pustaka Sarwono Prawirohardjo, 2.

Champion, V. L., \& Skinner, C. S. (2008). The health belief model. Health Behavior and Health Education: Theory, Research, and Practice, 4, 45-65.

Conner, M., \& Norman, P. (2005). Predicting Health Behaviour. Open University Press. Retrieved from https://books.google.co.id/books?id=oeFDBgAAQBAJ

Edmonds, E., Turner, L. W., \& Usdan, S. L. (2012). Osteoporosis knowledge, beliefs, and calcium intake of 
college students: Utilization of the health belief model. Open Journal of Preventive Medicine. https://doi.org/10.4236/ojpm.2012.21005

Hall, L., Callister, L. C., Berry, J. A., \& Matsumura, G. (2007). Meanings of menopause: cultural influences on perception and management of menopause. In Journal of holistic nursing: official journal of the American Holistic Nurses' Association. https://doi.org/10.1177/0898010107299432

Harpaz, M., \& Wolff, R. (2012). Menopause Reset!: Reverse Weight Gain, Speed Fat Loss, and Get Your Body Back in 3 Simple Steps. Harmony/Rodale. https://books.google.co.id/books?id=VPPCkR3XALsC

Innstrand, S. (Ed.). (2012). Health promotion-theory and practice. Research Centre for Health Promotion and Resources

HiST/NTNU. https://www.ntnu.edu/documents/16848459/0/Health+Promotion+-+Theory+and+Practice.pdf

Javaheri Tehrani, F., Nikpour, S., Haji Kazemi, E. A., Sanaie, N., \& Shariat Panahi, S. A. (2014). The effect of education based on health belief model on health beliefs of women with urinary tract infection. International Journal of Community Based Nursing and Midwifery. https://doi.org/10.1111/ijun.12026

Khokhar, S. (2013). Knowledge, attitude and experience of menopause. Pakistan Journal of Medical Research, $52(2), 42 \mathrm{~A}$.

Melby, M. K., Lock, M., \& Kaufert, P. (2005). Symptom reporting at menopause: a review of cross-cultural findings. Human Reproduction Update, 11(5), 495-512. https://doi.org/10.1093/humupd/dmi018

Moilanen, J. M., Aalto, A. M., Raitanen, J., Hemminki, E., Aro, A. R., \& Luoto, R. (2012). Physical activity and change in quality of life during menopause -an 8-year follow-up study. Health and Quality of Life Outcomes. https://doi.org/10.1186/1477-7525-10-8

Murdaugh, C. L., Pender, N. J., \& Parsons, M. A. (2018). Health Promotion in Nursing Practice (8th ed.). Pearson. https://books.google.co.id/books?id=Bq2ltAEACAAJ

Murti, B. (2003). Prinsip dan metode riset epidemiologi.

Rachman, A., Soewondo, P., Setiadi, S., Kusumawijaya, K., Baziad, A., \& Witjaksono, J. (2004). Terapi sulih hormon pada wanita perimenopause. Retrieved from https://www.scribd.com/doc/130860365/Terapi-Sulih-Hormon-Pada-Wanita-Perimenopause

Rostiana, T., \& Kurniati, N. (2009). Kecemasan Pada Wanita Yang Menghadapi Menopause. Jurnal Ilmiah Psikologi Gunadarma. https://doi.org/10.35760/psi

Simangunsong, D. E. (2009). Hubungan Karakteristik Wanita Perimenopause Dengan Pemanfaatan Pelayanan Kesehatan Di Kota Pematangsiantar. Universitas Sumatera Utara.

Sriwaty, I., \& Nuryoto, S. (2015). Pengaruh Psikoedukasi Menopause Dan Relaksasi Untuk Menurunkan Kecemasan Wanita Pre Menopause. HUMANITAS. https://doi.org/10.26555/humanitas.v12i1.3825

Williams, D. M., \& Rhodes, R. E. (2016). The confounded self-efficacy construct: Conceptual analysis and recommendations for future research. Health Psychology Review, 10(2), 113-128. https://doi.org/10.1080/17437199.2014.941998

Zohrehkhoshnood, A. M., Mohammadi, E., \& Haji Zadeh, E. (2015). Comparative Survey the Effect of Education Based Program on Health Belief Model for The Use Osteoporosis Preventive Behaviors of The Girl" S Osteoporotic and Non-Osteoporotic Mothers. Sch. J. App. Med. Sci, 3(6A), 2200-2206.

\section{Copyrights}

Copyright for this article is retained by the author(s), with first publication rights granted to the journal.

This is an open-access article distributed under the terms and conditions of the Creative Commons Attribution license (http://creativecommons.org/licenses/by/4.0/). 